\title{
Microsites and early litter decomposition patterns in the soil and forest canopy at regional scale
}

\author{
Yonatan Aguilar-Cruz (D) José G. García-Franco • Gerhard Zotz $\mathbb{D}$
}

Received: 8 May 2020/ Accepted: 26 September 2020/Published online: 13 October 2020

(C) The Author(s) 2020

\begin{abstract}
Plant litter decomposition is a key ecological process that is mostly studied at the forest floor. However, decomposition generally starts in the canopy. In this study, we evaluated the effect of litter composition and climate on the initial phase of decomposition in the soil and two contrasting types of canopy microsites along an elevational gradient (0-2200 $\mathrm{m}$ a.s.1.). To this end, we incubated standard material composed by green (fast decomposing) and rooibos (slow decomposing) tea bags for three months. Tea bags were placed in soil (buried at $5 \mathrm{~cm}$ ) and in the canopy at ca. $5 \mathrm{~m}$ above the ground in "micro-
\end{abstract}

Responsible Editor: Myrna Simpson

Electronic supplementary material The online version of this article (https://doi.org/10.1007/s10533-020-00705-3) contains supplementary material, which is available to authorized users.

Y. Aguilar-Cruz $(\bowtie) \cdot$ G. Zotz

Institut für Biologie und Umweltwissenschaften, AG

Funktionelle Ökologie der Pflanzen, Carl von Ossietzky

Universität Oldenburg, Postfach 2503, 26111 Oldenburg,

Germany

e-mail: yonatan.aguilar.cruz@uol.de

G. Zotz

e-mail: gerhard.zotz@uol.de

J. G. García-Franco

Red Ecología Funcional, Instituto de Ecología AC,

91000 Xalapa, Veracruz, Mexico

e-mail: jose.garcia.franco@inecol.mx wetlands" (tank bromeliads) and dry crown microsites (branches). Along the elevational gradient, green tea decomposed faster than rooibos tea in all microsites and forests. Mass loss for both tea types was lowest on branches at all sites, except for green tea in a wet forest where decomposition did not significantly differ among microsites. In wet forests, decomposition did not differ between bromeliads and soil, while in a dry forest, decomposition was faster in bromeliads. We found that the effects of climatic variables [monthly average temperature (TEMP) and total precipitation (PREC) for the incubation months] on decomposition differed between microsites. Along the elevational gradient, the mass loss in soil was positively correlated with TEMP but not with PREC, whereas on branches, mass loss was negatively correlated with TEMP and positively correlated with PREC. Unlike on branches, mass loss in bromeliads slightly decreased with PREC and increased with TEMP. Our study shows that microsite conditions interact with climate (TEMP and PREC) leading to differences in the general decomposition patterns in the forest canopy.

Keywords Arboreal soil - Elevational gradient - Tea bag index $\cdot$ Epiphytes $\cdot$ Bromeliads 


\section{Introduction}

Plant litter decomposition is a key ecological process that involves a series of physical, chemical, and biological processes that transform organic matter into increasingly stable forms, contributing to soil fertility, long-term carbon storage, and nutrient regeneration (Berg and McClaugherty 2014). This process is commonly divided in two stages: an early phase, stimulated by high levels of nutrients such as N, P and $\mathrm{S}$ in which water soluble substances and non-lignified cellulose and hemicellulose are leached and decomposed, and a late phase, when mainly lignified materials remain and litter degradation is dominated by lignin mass loss (Ibrahima et al. 1995; Coûteaux et al. 1995; Berg and McClaugherty 2014). Although plant litter decomposition primarily takes place on the forest floor, degradation of aboveground plant material generally begins in the canopy (Fonte and Schowalter 2004).

In a forest canopy, tree leaves may be colonized by pioneer decomposer organisms that start decomposition even before abscission (Šnajdr et al. 2011; Vořrišsková and Baldrian 2013). Dying branches also start to decay before they fall and may lose nearly $40 \%$ of their original mass in the canopy (Swift et al. 1976). Furthermore, in many temperate, subtropical and tropical forests dead epiphytes, decaying bark, and tree litter are trapped in stable locations in the canopy where they stay long enough to rot and form arboreal soil (Delamare-Deboutteville 1948; Nadkarni 1984; Hofstede et al. 2001; Fonte and Schowalter 2004; Enloe et al. 2006; Díaz et al. 2010). This phenomenon is particularly important in forests where the atmospheric humidity is high and epiphytes and littertrapping plants (sensu Zona and Christenhusz 2015) are abundant, e.g. tropical montane forests, tropical rain forests and temperate rain forests (Sugden and Robins 1979; Nadkarni 1984; Álvarez-Sánchez and Guevara 1999; Hofstede et al. 2001; Díaz et al. 2010). In such ecosystems litter-trapping plants can intercept up to $50 \%$ of total litterfall (Álvarez-Sánchez and Guevara 1999; Dearden and Wardle 2008), and together with epiphytes, this trapped litter provides enough source material to develop thick layers of arboreal soil (Nadkarni 1984; Hofstede et al. 2001; Díaz et al. 2010). For example, in an epiphyte-rich forest in Chile, epiphyte biomass may add 40-150\% of photosynthetic biomass to the tree crowns, and litter trapping bromeliads enhance organic matter deposition and retention in the canopy, accumulating more than $50 \%$ of the total arboreal soil (Díaz et al. 2010).

This arboreal soil (AS) formed and accumulated in the canopy can be defined as a Histosol (Nadkarni et al. 2002; Enloe et al. 2006) in which, as in terrestrial soils, pedogenic processes operate over time e.g. organic matter decomposition and nutrient mineralization (Vance and Nadkarni 1990; Bermudes and Benzing 1991; Paoletti et al. 1991; Inselsbacher et al. 2007). Furthermore, AS is a rich habitat for invertebrates and microbes which are common in the pedosphere (Nadkarni and Longino 1990; Paoletti et al. 1991; Fragoso and Rojas-Fernández 1996; Lindo and Winchester 2006). Considering that AS and terrestrial soil share general processes (decomposition and mineralization of nutrients) and functional groups of biota, decomposition in the canopy should be controlled by the same three essential factors that control decomposition in the terrestrial soil: (1) climate (Berg et al. 1993; Aerts 1997; Bradford et al. 2016); (2) litter chemical composition (Aerts 1997; Cornwell et al. 2008; Zhang et al. 2008), and (3) biota (Seastedt 1984; Verhoef and Brussaard 1990; Wall et al. 2008).

However, information on decomposition in the canopy is still scarce, and observations are inconsistent. Some studies have found that decay in the canopy is slower than in terrestrial soil when litter is incubated on branches and limb junctions (Nadkarni and Matelson 1991; Clark et al. 1998; Lindo and Winchester 2007; Li et al. 2014), while others report that decomposition can be as fast or even faster than in the pedosphere when this process takes place in the canopy of understory plants or epiphytes such as tank bromeliads (Paoletti et al. 1991; Dearden and Wardle 2008). This discrepancy may be the result of differences in biotic and abiotic conditions occurring at a fine spatial scale. Branches are dry crown microsites (Zotz and Hietz 2001; Stuntz et al. 2002) where the environmental conditions can be harsh for decomposers, whereas epiphytes can ameliorate environmental challenges (Stuntz et al. 2002; Scheffers et al. 2014; Zotz et al. 2020), and increase the density and diversity of decomposer (Paoletti et al. 1991; Pittl et al. 2010). Consequently, different decomposition patterns in the canopy can emerge at different microsites, and climatic controls at a regional scale can be only a surrogate for differences in microclimate (Bradford et al. 2016, 2017). 
Canopy decomposition studies are typically not standardized. Although most studies use the litterbag technique, protocols differ substantially in regard to litter type, incubation time, and bag characteristics such as size and mesh opening (Paoletti et al. 1991; Clark et al. 1998; Lindo and Winchester 2007; Dearden and Wardle 2008; Cardelús 2010; Prescott 2010; Li et al. 2014; LeCraw et al. 2017). As a result, studies are only partially comparable as is the identification of common drivers of litter decomposition using such heterogeneous data (Didion et al. 2016; Djukic et al. 2018). Recently, Keuskamp et al. (2013) proposed the use of two types of commercially available tea bags (green and rooibos) as standard substrates to study the effect of litter composition and environmental factors on litter decomposition across sites and ecosystems (Keuskamp et al. 2013; Didion et al. 2016; Djukic et al. 2018; Petraglia et al. 2019). These two tea types differ chemically: Green tea has more water-soluble substances and higher cellulose content and is expected to decompose faster, while rooibos tea with its high nonsoluble compounds and lignin should experience slower decomposition (Keuskamp et al. 2013; Didion et al. 2016; Djukic et al. 2018).

In this study, we used these standard tea bags to study litter decomposition in the canopy and in terrestrial soil along an elevational gradient in Veracruz, Mexico. In particular, we (1) compared the early decomposition of two litter types between two contrasting microsites in the canopy (branches and tank bromeliads) and terrestrial soil in five different forests, and (2) evaluated the effect of litter composition, microsite and climatic conditions (temperature and precipitation) on the initial phase of decomposition. We hypothesized that for both tea types: (1) decomposition differs among microsites and sites, (2) decomposition in the canopy is slower in dry microsites (branches) compared to wetter microsites (bromeliads) and soil, and (3) the effects of climatic variables on decomposition at regional scale differ among microsites.

\section{Materials and methods}

Study area

The present study was conducted in the central part of Veracruz, Mexico, along an elevational gradient formed by the eastern and southeastern slopes of the extinct volcano Cofre de Perote. Along this gradient, elevation ranges from sea level to $4250 \mathrm{~m}$ above the sea level across a geographical distance of less than $130 \mathrm{~km}$ (Fig. 1). The geomorphology is characterized by mountains, hills, and low plains of Cenozoic volcanic rocks, Meso-Cenozoic sedimentary rocks, and lacustrine and marine sediments (CONABIO 2011). The main soil groups are Andosols in the upper part of the gradient; Phaeozems and Vertisols combined with Lithosols, Rendzinas, and Luvisols in the middle part; and Vertisols, Regosols and Gleysols in the lower part (CONABIO and INIFAP 1995). Mean annual temperature (MAT) decreases linearly with elevation and mean annual precipitation (MAP) peaks at 1500-2000 m a.s.l. (Fig. 2). Remarkably, nearly all the climate types of Mexico are found along this gradient (CONABIO 2011). Varied climatic conditions and the complex topography maintain highly diverse plant communities, which have been classified into more than 27 elevational vegetation zones (Cházaro-Basáñez 1992). In this area, five study sites were selected at elevations of ca. 0, 600, 1000, 1600 , and $2200 \mathrm{~m}$ a.s.l. corresponding with mangrove forest (Mandinga), semi-deciduous tropical forest (Palmarejo), tropical oak forest (Tres Pasos), and two different cloud forests (Capulines and El Zapotal), respectively (Table 1, Fig. 1).

\section{Tea material}

The decomposition experiment was carried out using the standard substrates proposed by Keuskamp et al. (2013), which consist of tea bags (Lipton, Unilever, Rotterdam, Netherlands) containing ca. $2 \mathrm{~g}$ of green tea (Camellia sinensis, EAN: 872270005552 5) or rooibos tea (Aspalathus linearis, EAN: 8722700 188438 ). Tea bag are all tetrahedron-shaped (each side ca. $5 \mathrm{~cm}$ ) and made of woven nylon with a mesh size of $0.25 \mathrm{~mm}$, which permits the entry of bacteria, fungi, and meso- and microfauna (Verhoef and Brussaard 1990; Bradford et al. 2002; Keuskamp et al. 2013).

\section{Tea bag experiment}

At each study site along the elevational gradient, we established three $15 \mathrm{~m} \times 15 \mathrm{~m}$ plots separated by at least $10 \mathrm{~m}$ (nested spatial design, 5 sites, 3 plots per 


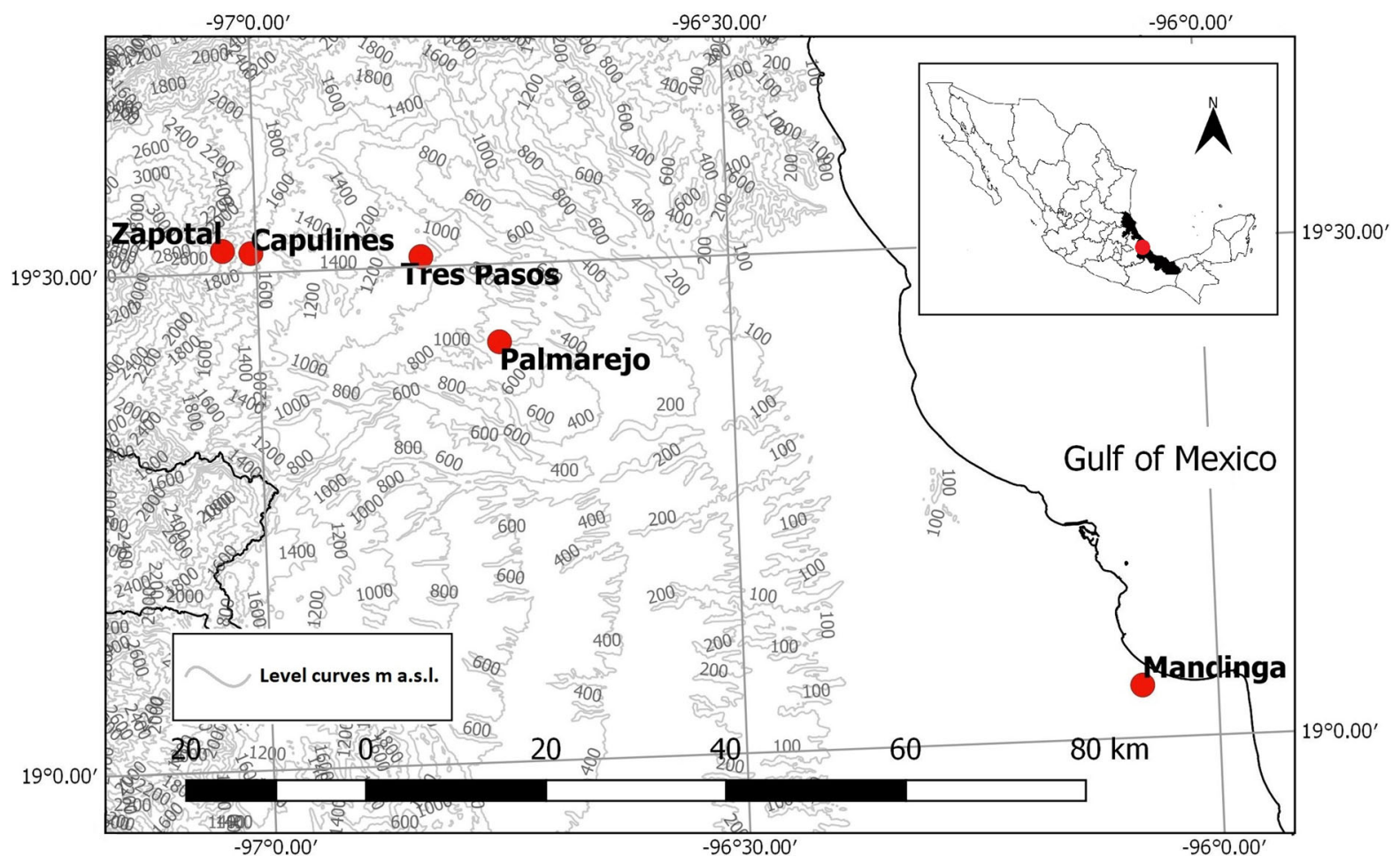

Fig. 1 Location of the five study sites along an elevational gradient in central Veracruz, Mexico

site). Height (estimated with clinometer) and diameter at breast height $(\mathrm{DBH})$ of all trees with a $\mathrm{DBH} \geq 5 \mathrm{~cm}$ were determined, and each tree was labelled and identified. Then, in each plot, five large trees (DBH > $20 \mathrm{~cm}$ ) were randomly chosen by assigning a number to all large trees and taking a random sample without replacement $(n=75)$. Near each plot, conspecifics of the previously selected trees were inspected for straight branches of ca. $7 \mathrm{~cm}$ in diameter $(\varnothing)$. Once located, the branches were cut using a manual saw, avoiding damage to the trees as much as possible. The straight parts of the branches without imperfections such as knots or holes were chosen, and $20 \mathrm{~cm}$ long sections $\left(\varnothing_{1}=7.1 \pm 0.5 \mathrm{~cm}, \varnothing_{2}=7.2 \pm 0.5 \mathrm{~cm}\right.$, means $\pm \mathrm{SD}, \mathrm{n}=75$ ) were cut and cleaned, removing all vascular and non-vascular epiphytes if present. Afterwards, a total of 75 medium- to large-sized tank bromeliads [maximum leaf length $>30 \mathrm{~cm}$ (average of the three longest leaves, LL)] without inflorescences, belonging to common species at each site (Table 1) were collected in the vicinity of the plots. All bromeliads were labeled, and the number and length (LL) of green leaves were recorded.
Subsequently, bromeliads and branch sections (hereinafter referred to as branches) were relocated on the selected trees at ca. $5 \mathrm{~m}$ above the ground $(5.3 \pm 0.3 \mathrm{~m}$, mean $\pm \mathrm{SD}, \mathrm{n}=75$, supplementary material Fig. S1). For this purpose, bromeliads were randomly assigned in each forest to the experimental trees and relocated by fastening them to rigid polyvinyl chloride (PVC) rings. PVC rings were $5-\mathrm{cm}$ high with a diameter of $2.5,5.8$, or $7.6 \mathrm{~cm}$ depending on the size of the bromeliads (Fig. S2). Branches of the same species as the selected trees were fixed using angle brackets, adjusting the angle to $<5^{\circ}$ against the horizontal $\left(2.5 \pm 1.4^{\circ}\right.$, mean $\pm \mathrm{SD}$, $\mathrm{n}=75$, supplementary material Fig. S2). The inclination and height of the PVC rings and branches were controlled using a laser measuring tool (Model GLM 80 professional, Bosch, Stuttgart, Germany).

Before incubation started, tea bags were oven-dried at $70{ }^{\circ} \mathrm{C}$ for $48 \mathrm{~h}$, and the initial mass was recorded. Additionally, to estimate the initial amount of tea, 20 empty bags (10 green, 10 rooibos) were dried and weighed, and the average mass was subtracted from the initial mass of the tea bags. Afterwards, each bag was marked with a unique code on the white side of the 
(a)

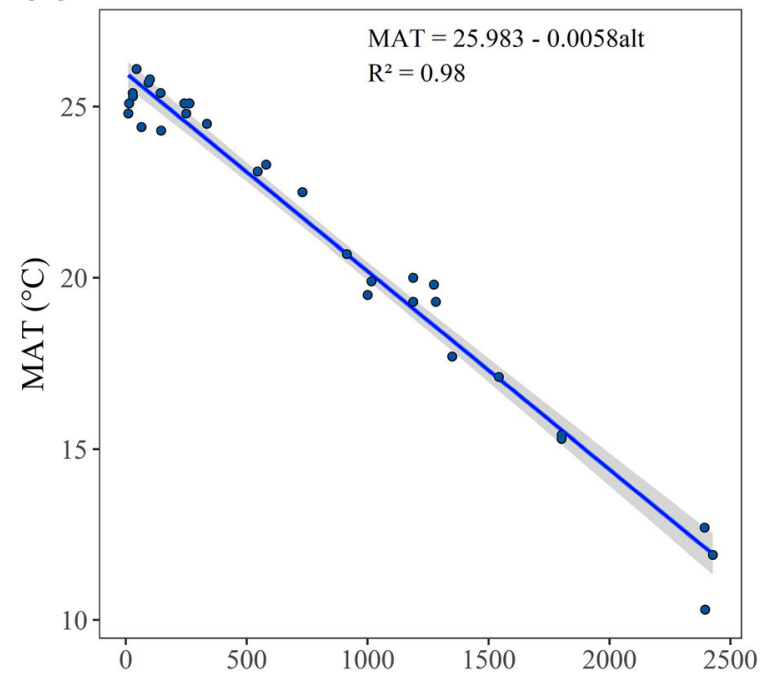

(c)

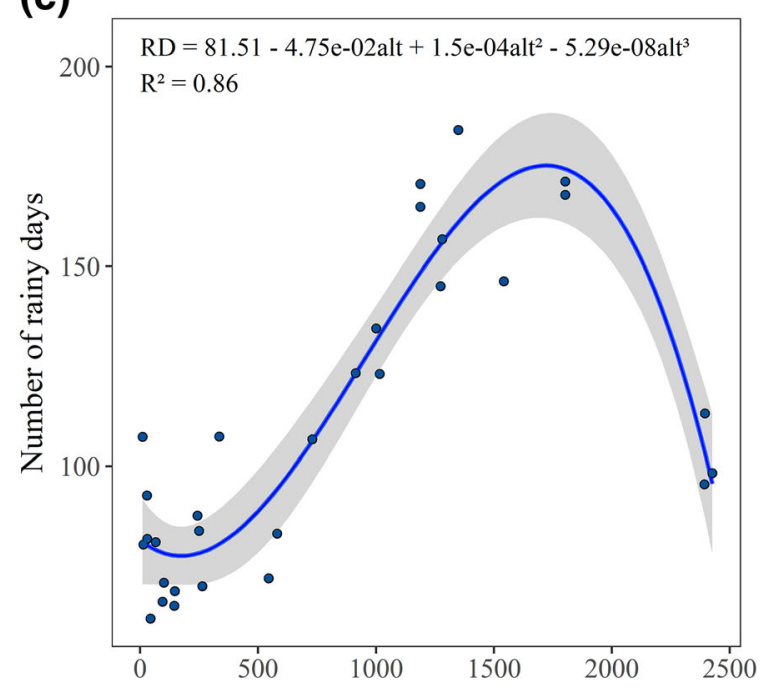

(b)

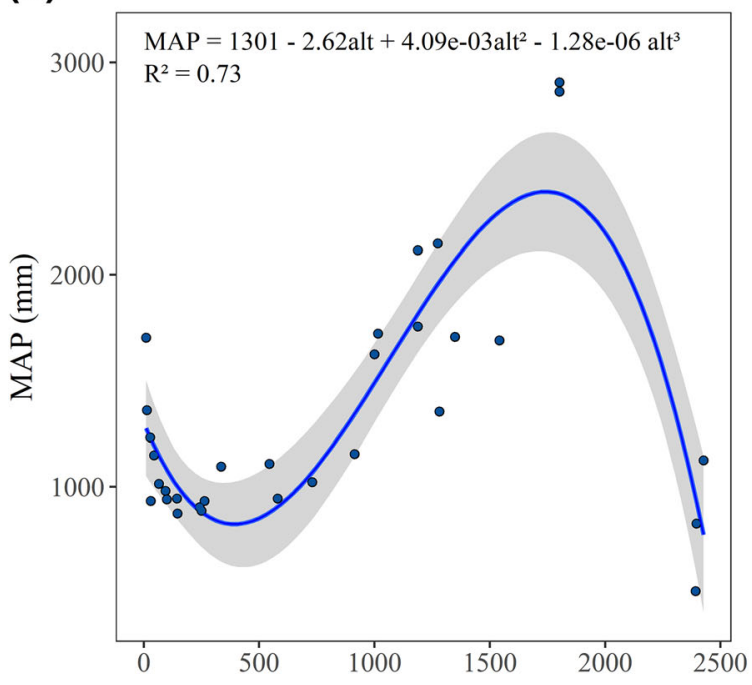

(d)

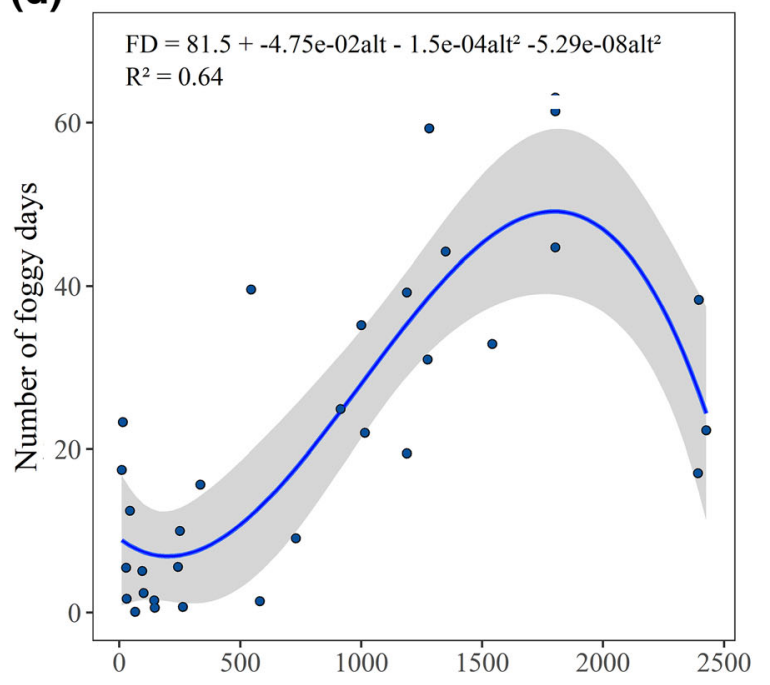

Elevation $m$ a.s.l.

Fig. 2 Relationships between elevation and mean annual temperature (MAT, a), mean annual precipitation (MAP, b), rainy days $(\mathrm{RD}, \mathbf{c})$, and foggy days $(\mathrm{FD}, \mathbf{d})$ in the study area. The

label with a permanent marker. For our experiment we performed a factorial design with three factors $(2 \times 3 \times 5, \mathrm{n}=450)$, tea type (green and rooibos), microsite (soil, branch and bromeliad), and site $(0$, 600, 1000, 1600, and $2200 \mathrm{~m}$ a.s.l). In November 2018, 75 pairs of tea bags (one green and one rooibos) were placed in the relocated tank bromeliads in the middle portion of the rosette and deep inside the leaf base. Additionally, 75 pairs were fixed onto the upper models are based on data from 31 climatic stations from 1951 to 2010 near the study sites along an elevational gradient in central Veracruz

surface of the branches using fishing lines, leaving a gap of ca. $5 \mathrm{~cm}$ between the two tea bags. Seventy-five pairs were also placed in the forest floor below the bromeliads and branches. These bags were buried in the upper $5 \mathrm{~cm}$ of the topsoil layer, additionally, they were tied with fishing lines to flags facilitating later recovery (supplementary material Fig. S3).

Tea bags were retrieved from the bromeliads, branches, and soil in February 2019 after 90 days of 
Table 1 Characterization of the study sites along an elevational gradient in central Veracruz, Mexico

\begin{tabular}{|c|c|c|c|c|c|}
\hline Site (vegetation) & $\begin{array}{l}\text { Elevation } \\
\text { (m a.s.1.) }\end{array}$ & $\begin{array}{l}\mathrm{MAT}^{\mathrm{a}} \\
\left({ }^{\circ} \mathrm{C}\right)\end{array}$ & $\begin{array}{l}\text { MAP }^{\mathrm{a}} \\
(\mathrm{mm})\end{array}$ & Soil type ${ }^{b}$ & $\begin{array}{l}\text { Common large tank } \\
\text { bromeliads }\end{array}$ \\
\hline Mandinga (Mangrove) & 5 & 25.9 & 1320 & Eutric Gleysol & $\begin{array}{l}\text { Tillandsia dasyliriifolia } \\
\text { Aechmea bracteata }\end{array}$ \\
\hline $\begin{array}{l}\text { Palmarejo (Semi-deciduous tropical } \\
\text { forest) }\end{array}$ & 650 & 22.2 & 920 & $\begin{array}{l}\text { Lithosol and orthic } \\
\text { Luvisols }\end{array}$ & $\begin{array}{l}\text { Aechmea bracteata } \\
\text { Tillandsia fasciculata } \\
\text { Tillandsia limbata }\end{array}$ \\
\hline Tres Pasos (Tropical oak forest) & 1005 & 20.1 & 1490 & Haplic Phaeozem & $\begin{array}{l}\text { Aechmea nudicaulis } \\
\text { Tillandsia limbata } \\
\text { Tillandsia fasciculata } \\
\text { Tillandsia heterophylla }\end{array}$ \\
\hline Capulines (Cloud forest) & 1650 & 16.4 & 2490 & Humic Andosol & $\begin{array}{l}\text { Tillandsia macropetala } \\
\text { Tillandsia multicaulis } \\
\text { Tillandsia punctulata }\end{array}$ \\
\hline Zapotal (Cloud forest) & 2210 & 13.1 & 1830 & Humic Andosol & $\begin{array}{l}\text { Tillandsia imperialis } \\
\text { Tillandsia macropetala } \\
\text { Tillandsia multicaulis }\end{array}$ \\
\hline
\end{tabular}

${ }^{a}$ MAT and MAP data were estimated using the models shown in Fig. 2

${ }^{\mathrm{b}}$ Soils types were obtained from CONABIO and INIFAP (1995)

incubation, transported to the laboratory in individual plastic bags, cleaned of soil and roots, and oven-dried for $48 \mathrm{~h}$ at $60{ }^{\circ} \mathrm{C}$. After cleaning, the mass of the remaining tea (without bags) was recorded. A total of 26 tea bags were lost during the experiment or discarded because they were torn or had larger holes (11 on branches, 2 in bromeliads, and 13 in soil).

\section{Statistical analysis}

\section{Relative importance of microsite and site on mass loss}

Litter decomposition was calculated as a proportion of tea mass loss. Beta generalized linear mixed-effects models (GLMM) with a logit link function were performed to test for differences in litter decomposition among microsites and sites for each tea type using the glmmTMB package (Brooks et al. 2017). The beta regression is useful for modeling of data limited to the $0-1$ interval and gives less biased estimates of the mean compared to transformation-based approaches (Douma and Weedon 2019). Fixed factors for these models are microsite (categorical with three levels), site (categorical with five levels) and their interaction. For these models we used plot nested to site as a random effect to account the spatial dependence of observations. The significance for each variable was evaluated with the Wald chi-square test and if the interaction among microsite and site was significant, multiple comparisons between microsites within each site were tested applying Tukey post hoc contrast tests with the lsmeans package (Lenth 2016). Additionally, to quantify the difference sources of variation in the data we use a Beta GLMM with a logit link function model with microsite set as fixed factor and tea type (categorical with two levels) and site as random factors (supplementary material Table S1). Separate analysis for each tea type were performed to investigate whether site, microsite and individual tea bags accounted differently for the variation of each tea type (supplementary material Table S2). Different variance components of the mixed models were obtained using the insight package (Lüdecke et al. 2019).

\section{Effects of litter composition, climate and microsite on mass loss}

Since detailed climatic information was not available for the study sites and some of them share the same nearest climatic station, monthly average temperature 
Table 2 Estimated regression parameters, standard errors, z-values, p-values and random effects for the Beta GLMM fitted with temperature, precipitation, microhabitat, tea type, temperature $\times$ precipitation, temperature $\times$ microhabitat and precipitation $\times$ microhabitat set as fixed effects, and plot nested to site as random effect

\begin{tabular}{|c|c|c|c|c|}
\hline Coefficients & Estimate & SE & z.value & Pr. $(>|z|)$ \\
\hline Intercept & -0.39 & 0.04 & -8.92 & $<0.001 * * *$ \\
\hline Temperature & -0.14 & 0.04 & -3.18 & $0.001 * *$ \\
\hline Precipitation & 0.11 & 0.04 & 2.77 & $0.006 * *$ \\
\hline Bromeliad & 0.67 & 0.04 & 19.20 & $<0.001 * * *$ \\
\hline Soil & 0.64 & 0.04 & 17.80 & $<0.001 * * *$ \\
\hline Tea Red & -1.64 & 0.03 & -56.68 & $<0.001 * * *$ \\
\hline Temperature: Precipitation & -0.27 & 0.04 & -6.13 & $<0.001 * * *$ \\
\hline Temperature:Bromeliad & 0.10 & 0.05 & 1.97 & $0.049 *$ \\
\hline Temperature:Soil & 0.35 & 0.05 & 6.77 & $<0.001 * * *$ \\
\hline Precipitation:Bromeliad & -0.18 & 0.05 & -3.67 & $<0.001 * * *$ \\
\hline Precipitation:Soil & -0.01 & 0.05 & -0.21 & 0.84 \\
\hline
\end{tabular}

Random effects

\begin{tabular}{lc}
\hline$\sigma^{2}$ Site:Plot & 0.003 \\
$\mathrm{~N}_{\text {Site }}$ & 5 \\
$\mathrm{~N}_{\text {Plot }}$ & 3 \\
Observations & 424 \\
Marginal R ${ }^{2}$ Conditional R ${ }^{2}$ & $0.99 / 0.99$ \\
\hline
\end{tabular}

Temperature and precipitation data for the incubation months (November-February) obtained from WorldClim (average climate for the period 1970-2000)

Coefficients significant at $\mathrm{p}<0.05(*),<0.01(* *)$ and $<0.001(* * *)$

(TEMP) and total precipitation (PREC) data for the incubation months (November-February) were obtained from the $1 \mathrm{~km}^{2}$ spatial resolution dataset from WorldClim (Fick and Hijmans 2017). These values represent the average for the years 1970-2000. To assess the congruency of the climatic data we compared the TEMP and PREC values against temperature and precipitation data for the period November-February from 31 climatic stations (average for the years1951 to 2010) located along the gradient. Climatic data obtained from climatic stations and WorldClim were highly correlated (TEMP: $r=0.98$, $\mathrm{p}<0.001$; PREC: $\mathrm{r}=0.97, \mathrm{p}<0.001$, Pearson's product moment correlation).

To model litter decomposition as a function of the litter composition, climate and microsite a Beta GLMM with a logit link function was fitted. Fixed variables for the model are microsite, TEMP (continuous), PREC (continuous) and tea type. The interaction terms are TEMP $\times$ microsite, $P R E C \times$ microsite and TEMP $\times$ PREC. We use plot nested to site as random effect to account the spatial dependence of observations. Afterwards, if the interaction among microsite and the climatic variables were significant, we tested the effect of each climatic variable and tea type on mass loss for each microsite (branch, bromeliad and soil) using individual Beta GLMMs. For these models we used a logit link function and plot nested to site set as random effect.

Although the bromeliads used in our experiment were all relatively large $(\mathrm{LL}>30 \mathrm{~cm})$, they still differed in size. Therefore, we tested for a possible effect of plant size on tea decomposition along the elevation gradient using a beta GLMM with a logit link function and plant size (LL, continuous) set as 


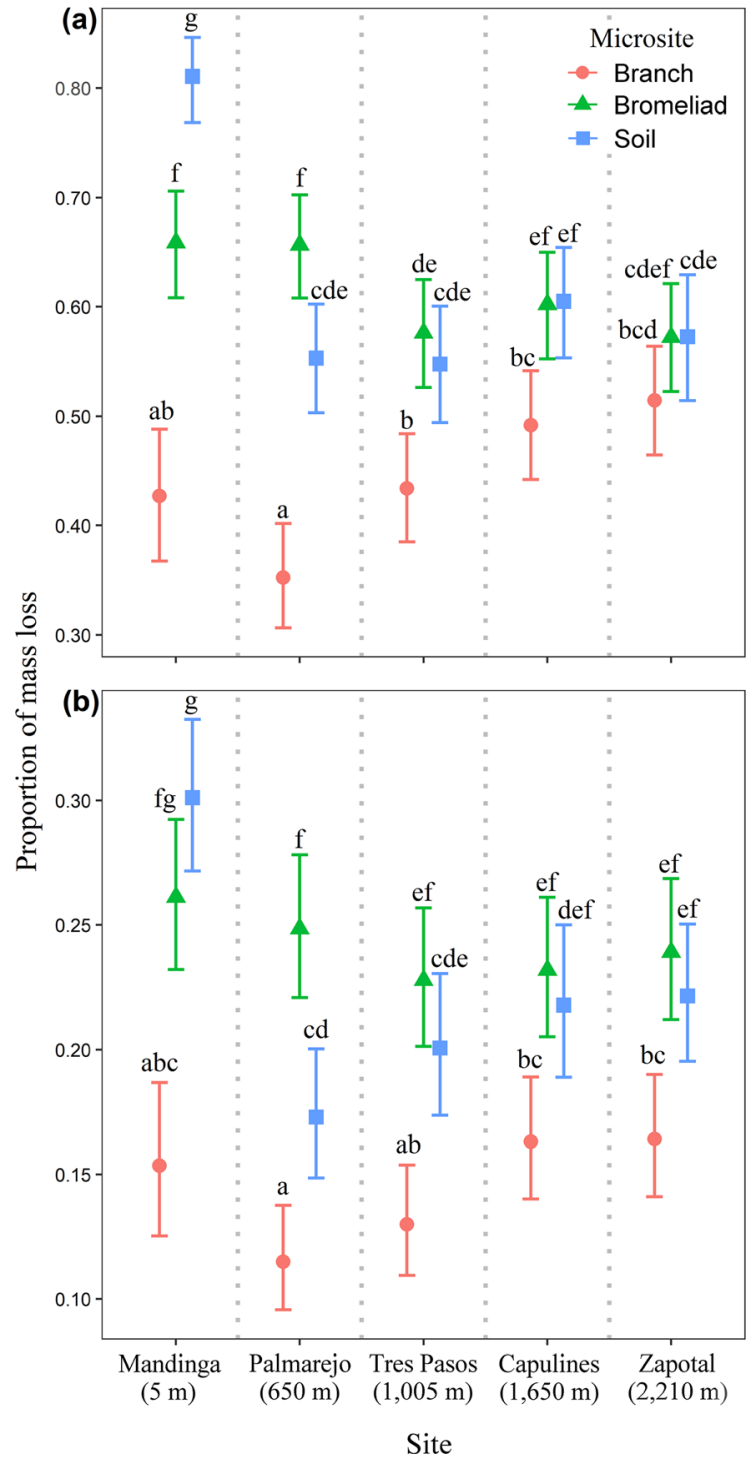

Fig. 3 Mass loss (LS mean and 95\% CIs) of green $(\mathbf{a}, \mathrm{n}=212$ ) and rooibos $(\mathbf{b}, \mathrm{n}=212)$ tea in three microsites and five different forests along an elevational gradient. Mandinga (mangrove forest), Palmarejo (semi-deciduous tropical forest), Tres Pasos (tropical oak forest), and Capulines and Zapotal (cloud forest). Different letters indicate significant differences (Tukey multiple comparisons, $\mathrm{p}<0.05$ ) between microsites and sites. The numbers between brackets indicate the elevation of the study sites. Note the different scales of the y-axes between plots

fixed covariate and tea type and site as random factors (supplementary material Table S3, Fig S4).

All statistical analyses were performed using $\mathrm{R}$ version 3.6.2 (R Core Team 2020). Simulated observations were obtained from the fitted models and plotted against the observed values, and residual plots of the models were visually inspected for deviations from assumptions (supplementary material Figs. S5$\mathrm{S} 10$ ). Goodness of fit for the models were calculated based on marginal and conditional $\mathrm{R}^{2}$ (Nakagawa and Schielzeth 2013).

\section{Results}

Relative importance of microsite and site on mass loss

Along the elevational gradient, almost three times as much green tea mass $(56 \pm 12 \%$, mean \pm SD) than rooibos tea mass $(20 \pm 6 \%)$ was lost during the experiment. For both tea types there was a significant interaction between microsite and site on mass loss [green $\left(\chi^{2}=162.9, \quad \mathrm{df}=8, \quad \mathrm{p}<0.001\right)$, rooibos $\left(\chi^{2}=58.2, \mathrm{df}=8, \mathrm{p}<0.001\right)$, Fig. 3)]. Tukey posthoc tests for both tea types indicated that among microsites, loss of tea mass was consistently smallest on branches along the elevation gradient. Decomposition on branches was higher at relatively wet cloud forests (Capulines and Zapotal) and lower in a dry forest (Palmarejo, Fig. 3a, b). Only for green tea in Zapotal cloud forest decomposition was not significantly different among branches, bromeliads and soil (Fig. 3a). In soil and bromeliads, tea mass loss was higher for the former at the mangrove site and for the latter in the mangrove and the relatively dry forest of Palmarejo. In wetter forests at the middle and upper part of the gradient (Tres Pasos, Capulines, and Zapotal), tea decomposition in bromeliads and soil did not differ significantly (Fig. 3a, b). The analysis of data variation showed that $83 \%$ of the variation in mass loss was related to tea type while $11 \%$ was related to microsite and $4 \%$ to the overall site characteristics (supplementary material Table S1). A separate analysis for each tea type reveled only small variation in the mass loss among sites $\left(\sigma^{2}<0.05\right)$, and tea bags $\left(\sigma^{2}<0.01\right)$ for green and rooibos tea (supplementary material Tables $\mathrm{S} 2$ ). 


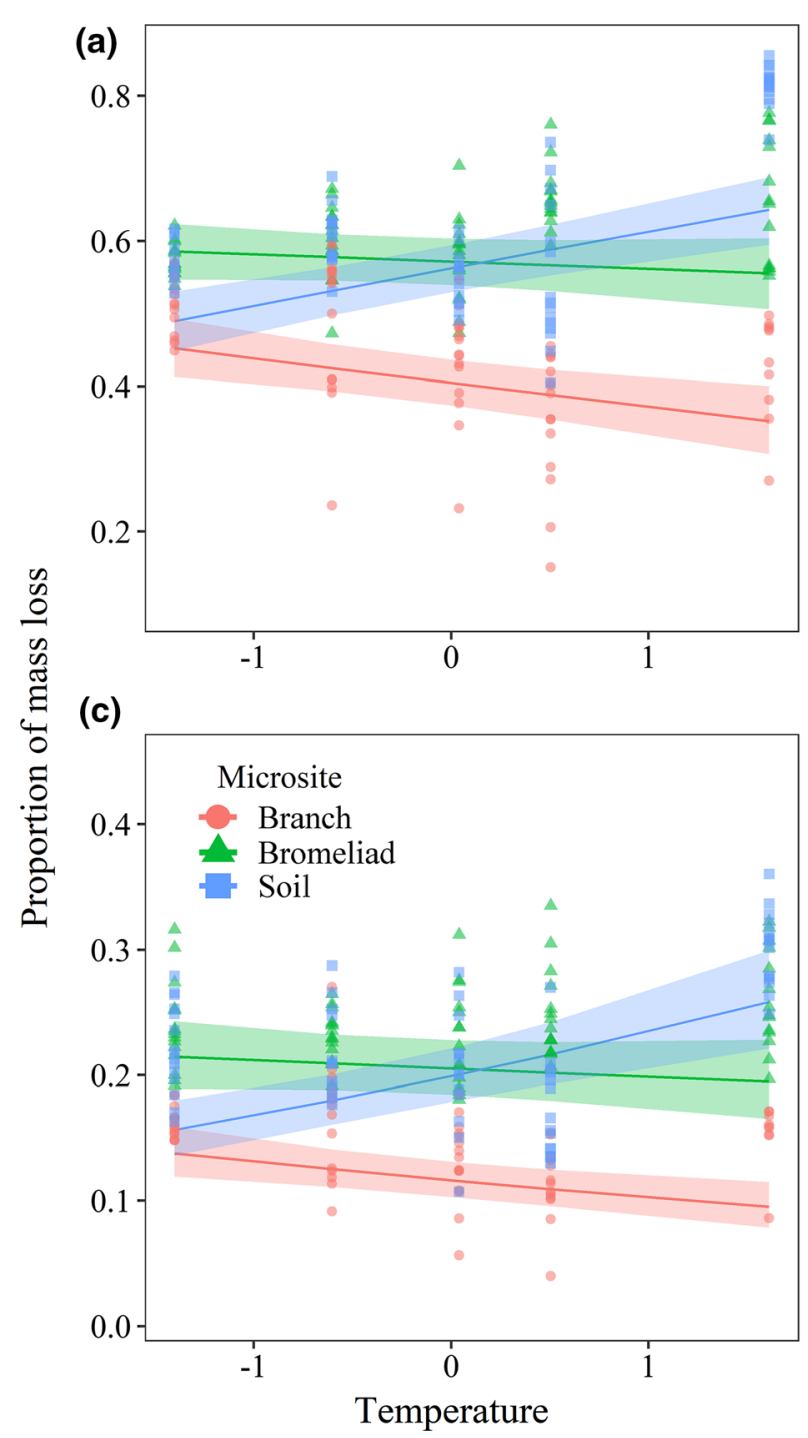

Fig. 4 Proportion of mass loss versus temperature (a-c) and precipitation (b-d) for green $(\mathbf{a}, \mathbf{b})$ and rooibos tea (c, d). Temperature and precipitation were obtained from the WorldClim dataset for the period November-February (average climate 1970-2000). The regression lines were obtained from a Beta GLMM with tea type, microsite, temperature,

\section{Effects of litter composition, climate and microsite on mass loss}

Our model showed a significant effect of tea type on mass loss $\left(\chi^{2}=3212.9\right.$, df $\left.=1, \mathrm{p}<0.001\right)$, and a similar response of mass loss to climatic variables for both tea types. However, along the elevation gradient the effects of climatic variables on decomposition differed between microsites, as revealed by the

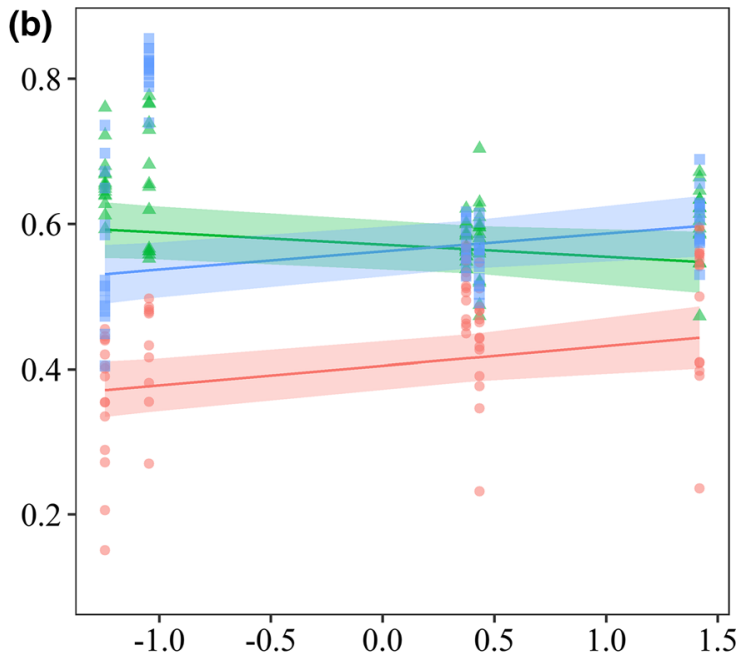

(d)

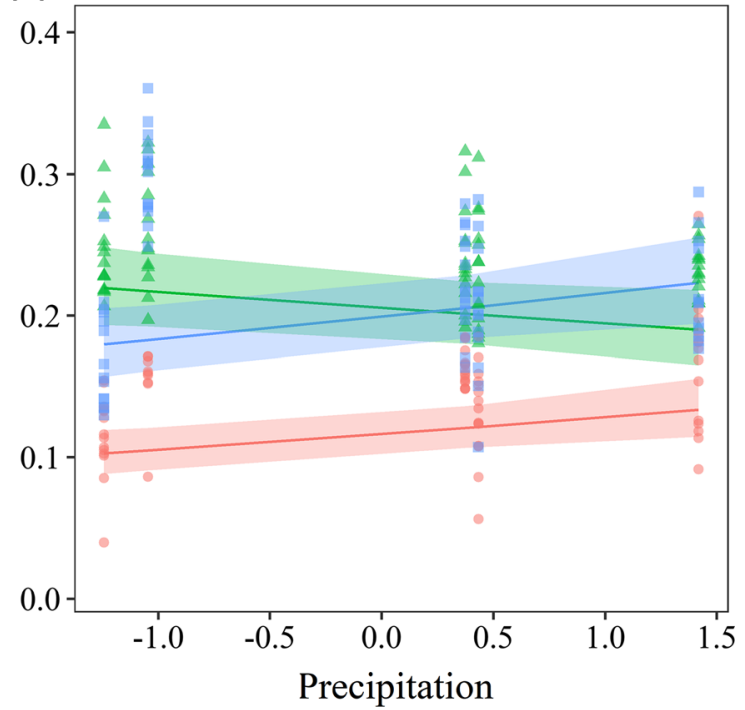

precipitation, and the interaction terms temperature $\times$ microsite, precipitation $\times$ microsite and temperature $\times$ precipitation set as fixed effects, and plot nested within site as random effect. Band shows $95 \%$ confidence intervals. A summary of the models is presented in Table 2

significant interaction among microsite and TEMP $\left(\chi^{2}=49.9\right.$, df $=2, \mathrm{p}<0.001$, Fig. 4) and PREC $\left(\chi^{2}=17.4\right.$, df $=2, \mathrm{p}<0.001$, Fig. 4). Tea mass loss in soil was positively correlated with TEMP but not with PREC while on branches decomposition decreased with TEMP and increased with PREC (Table 3). In bromeliads decomposition varied less, increasing only slightly with TEMP and, in contrast to branches, decreasing slightly with PREC (Table 3). 
Table 3 Estimated regression parameters, standard errors, z-values, p-values and random effects for Beta GLMMs fitted for each microhabitat (branch, bromeliad and soil) using tea type and climatic variables (temperature or precipitation) as fixed effects and plot nested to site as random effect

\begin{tabular}{|c|c|c|c|c|}
\hline Coefficients & Estimate & SE & $\mathrm{z}$ value & Pr. $(>|z|)$ \\
\hline \multicolumn{5}{|l|}{ Temperature } \\
\hline \multicolumn{5}{|c|}{ Bromeliad $\left(\mathrm{n}=148, \sigma^{2}\right.$ Site:Plot $\left.=0.002\right)$} \\
\hline Intercept & 0.46 & 0.03 & 17.15 & $<0.001 * * *$ \\
\hline Temperature & 0.09 & 0.02 & 4.35 & $<0.001 * * *$ \\
\hline Tea rooibos & -1.61 & 0.04 & -43.25 & $<0.001 * * *$ \\
\hline \multicolumn{5}{|c|}{ Branch $\left(n=139, \sigma_{\text {Site:Plot }}^{2}=0.03\right)$} \\
\hline Intercept & -0.22 & 0.05 & -4.08 & $<0.001 * * *$ \\
\hline Temperature & -0.13 & 0.05 & -2.52 & $0.01 *$ \\
\hline Tea rooibos & -1.55 & 0.05 & -28.32 & $<0.001 * * *$ \\
\hline \multicolumn{5}{|c|}{ Soil $\left(n=137, \sigma_{\text {Site:Plot }}^{2}=0.07\right)$} \\
\hline Intercept & 0.51 & 0.08 & 6.72 & $<0.001 * * *$ \\
\hline Temperature & 0.21 & 0.07 & 2.95 & $0.003 * *$ \\
\hline Tea rooibos & -1.79 & 0.05 & -37.98 & $<0.001 * * *$ \\
\hline \multicolumn{5}{|l|}{ Precipitation } \\
\hline \multicolumn{5}{|c|}{ Bromeliad $\left(\mathrm{n}=148, \sigma^{2}\right.$ Site:Plot $\left.=0.002\right)$} \\
\hline Intercept & 0.46 & 0.03 & 17.31 & $<0.001 * * *$ \\
\hline Precipitation & -0.09 & 0.02 & -4.42 & $<0.001 * * *$ \\
\hline Tea rooibos & -1.61 & 0.04 & -43.21 & $<0.001 * * *$ \\
\hline \multicolumn{5}{|c|}{ Branch $\left(\mathrm{n}=139, \sigma^{2}\right.$ Site:Plot $\left.=0.02\right)$} \\
\hline Intercept & -0.22 & 0.05 & -4.42 & $<0.001 * * *$ \\
\hline Precipitation & 0.15 & 0.05 & 3.25 & $0.001 * *$ \\
\hline Tea rooibos & -1.55 & 0.05 & -28.33 & $<0.001 * * *$ \\
\hline \multicolumn{5}{|c|}{ Soil $\left(\mathrm{n}=137, \sigma_{\text {Site:Plot }}^{2}=0.11\right)$} \\
\hline Intercept & 0.52 & 0.09 & 5.75 & $<0.001 * * *$ \\
\hline Precipitation & -0.11 & 0.09 & -1.26 & 0.2 \\
\hline Tea rooibos & -1.80 & 0.05 & -38.03 & $<0.001 * * *$ \\
\hline
\end{tabular}

Temperature and precipitation data for the incubation months (November-February) obtained from WorldClim (average climate for the period 1970-2000). Coefficients significant at p $<0.05(*),<0.01(* *)$ and $<0.001(* * *)$

Along the elevation gradient decomposition tended to converge in the upper part as TEMP decreased and PREC increased, and the differences between microsites were 40-80\% smaller than in the dry part of the gradient (Fig. 3).

\section{Discussion}

Litter composition is an important direct regulator of litter decomposition at the global scale (Enríquez et al. 1993; Zhang et al. 2008; Djukic et al. 2018). Based on incubations performed in the soil and canopy in different forests along an elevation gradient, we found that overall litter composition explained $83 \%$ of the variability of mass loss while $11 \%$ was related to microsite and $4 \%$ to the overall site characteristics. In a study using the same tea bags (green and rooibos) across nine biomes, Djukic et al. (2018) found a consistent pattern for soil in which about $65 \%$ of variability in initial litter decomposition at global scale was explained by litter type while $13 \%$ was related to biome.

As expected because of its much higher watersoluble fraction, green tea decomposed faster than rooibos tea in all microsites and forest types (Keuskamp et al. 2013). Water-soluble substances (reducing sugars, phenolics and soluble organic 
carbon), are easily leached from leaf litter during the first week of incubation accounting for more than $20 \%$ of dry mass loss during the early stage of decomposition (Nykvist 1963; Steinke et al. 1993). Accordingly, during this stage, leaching losses of green tea can exceed those of rooibos tea twofold, and this process may be more related to the mass loss than microbial mineralization (Djukic et al. 2018). Thus, the use of allochthonous and dried litter can increase leaching losses substantially and reduce the effect of mineralization of organic $\mathrm{C}$ during the first months of incubation by increasing the time to build a microbial community (Bärlocher 1991; Gessner 1991; Clein and Schimel 1994). Consequently, the use of fresh local litter, which already possess the microbial signature of the sites, may change the effect of leaching and microbial $\mathrm{C}$ mineralization on mass loss and may reduce the strong effect of litter composition that we found using tea bags. For example, Didion et al. (2016) found a difference of $4 \%$ in mass loss between the local litter (fast decomposition Fagus sylvatica vs. the recalcitrant Pinus nigra) buried into the soil at $5 \mathrm{~cm}$ depth in the first year of decomposition, compared to $27 \%$ between tea types, with rooibos tea losing much less mass than the recalcitrant local litter. Experiments in which both substrates are compared are still needed in order to corroborate the patterns found in this study and to have a better understanding of the importance of litter composition on decomposition in the canopy. Additionally, the results about decomposition in the soil should be interpreted with caution, since in our experiment tea bag were buried in the upper $5 \mathrm{~cm}$ of the topsoil layer which could increase decomposition by buffering temperature changes and moisture deficits in comparison to studies carried out on or above the soil surface where stronger microclimate fluctuations may limit microbial-driven litter decomposition (Parton and Logan 1981; Ashcroft and Gollan 2013; Lee et al. 2014; Liu et al. 2015).

In the five forests, mass loss was slower in the canopy than in the soil only when litterbags were placed on branches (Fig. 3a, b). A slower decomposition rate in the canopy has also been reported for tropical, subtropical and temperate forests, when litter bags were put on branches, trunk reiterations or limb junctions (Nadkarni and Matelson 1991; Lindo and Winchester 2007; Cardelús 2010; Li et al. 2014). The slower decay in these canopy microsites can be explained by their particular microclimatic conditions and interaction with decomposer communities. Frequent water shortage due to fast evaporative drying and sudden changes in temperature are common on branches (Nadkarni 1994; Bohlman et al. 1995; Zotz and Hietz 2001; Stuntz et al. 2002). These harsh conditions reduce leaching losses, the density and diversity of decomposers (Lindo and Winchester 2006, 2007) and affect the duration and intensity of their activity (Coûteaux et al. 1995; Manzoni et al. 2012; Wang et al. 2014).

Nonetheless, this pattern varied widely, and mass loss was as fast or even faster in the canopy when compared to the forest floor when tea bags were placed in the leaf rosettes of bromeliads (Fig. 3a, b). Epiphytes and litter-trapping plants affect temperature in the canopy, increase humidity (Ortega-Solís et al., 2017; Scheffers et al., 2014; Stuntz et al., 2002), and mitigate dispersal limitations of decomposers while increasing their density and diversity (Vance and Nadkarni 1990; Paoletti et al. 1991; Gora and Lucas 2019). Unlike branches, bromeliads represent humid habitats (Zotz et al. 2020) in which the density of fungi, bacteria, and invertebrate decomposers can be higher than in terrestrial soil (Paoletti et al. 1991; Pittl et al. 2010). Moreover, the capacity of bromeliads to store substantial amounts of water in the tanks (Zotz et al. 2020) can increase leaching losses. Due to these particular characteristics, tank bromeliads act as natural biodigesters that potentiate the decomposition process. Only the Mandinga mangrove was exceptional in this regard: decomposition in the soil was significantly higher than in bromeliads for green tea. We buried the tea bags during the wet season when floods are common (López-Portillo and Ezcurra 2002), which increases leaching losses and may provide more suitable conditions for microorganisms to utilize the substrate (Dick and Osunkoya 2000). Similarly, rapid losses of tea mass were observed in mangrove forests in the Mexican Pacific and Caribbean, where tea bags lost ca. $70 \%$ of their original mass after 3 months of incubation (Djukic et al. 2018).

Along the elevational gradient, the mass loss in the soil was positively correlated with TEMP but we did not find a significant effect of PREC. However, our results suggested that decomposition in the soil also increased with PREC, but the very different soil conditions in the mangrove forest could mask the effect of this variable. These results support the conclusions of other studies conducted at large scales 
in terrestrial ecosystems (Berg et al. 1993; Zhang et al. 2008). Interestingly, this pattern was not consistent across microsites. Several recent studies showed that regional heterogeneity in microsites is only poorly captured by site-mean climatic data, especially in the case of moisture, which may lead to a mismatch between local mechanisms and broad-scale patterns (Loescher et al. 2014; Bradford et al. 2017). In our study, we found that the effects of climatic variables on decomposition differed between microsites, as revealed the significant interaction between microsite and TEMP and PREC which may be related to different moisture conditions. Unlike in soil, decomposition on branches was positively correlated with PREC, but negatively with TEMP. Branches represent relatively dry microsites. Bark holds little water, even after rainfall, and most of this water $(>90 \%)$ is usually lost within $24 \mathrm{~h}$ (Callaway et al. 2002; Einzmann et al. 2015). Branches are generally more exposed to sunlight than soil, so dry periods typically prevail and are only punctuated by pulses of rainfall (Benzing 1987; Zotz 2016). Thus, as in other relatively dry systems, abiotic factors may dominantly influence mass loss in these microsites, and precipitation and solar radiation could be the most important drivers that promote decomposition (Santos et al. 1984; Coûteaux et al. 1995; Austin and Vivanco 2006; Yahdjian et al. 2006). We suggest that the negative correlation between decomposition and TEMP on branches is due to the fact that, in general, aridity increases with temperature along the gradient, which should reduce leaching losses and suppress microbial activity regardless of temperature (Davidson et al. 2006; Wang et al. 2014). However, water limitation diminishes in the upper part of the gradient, increasing decomposition on branches and reducing the decay gap between microsites (Fig. 3).

Quite different from branches, the water-filled tanks of bromeliads represent "wetlands" in the canopy (Martinson et al. 2010), in which mass loss slightly increased with TEMP and decreased with PREC. This pattern could be the result of the aerobicanaerobic cycles in tank bromeliads resulting from the duration of periods with and without water in the tanks. In the lower part of the elevational gradient where $<50 \%$ of days are rainy $(>0.1 \mathrm{~mm})$ and fog is uncommon, bromeliad tanks are probably frequently not filled with water (Zotz and Thomas 1999). After a few days without rain, bromeliad tanks can dry out and remain so until the next rain event (Zotz and Thomas 1999). Conversely, in an almost constantly filled tank, organic decomposition can lead to prevailing anoxic conditions (Martinson et al. 2010; Goffredi et al. 2011; Lehours et al. 2016) that are rarely interrupted by aerobic conditions during drier periods. Therefore, a low PREC and high TEMP can reduce the duration of flooded anoxic periods, promoting aerobic environments and increasing mass loss (Reddy and Patrick Jr 1975; Neckles and Neill 1994; Anderson and Smith 2002). However, in the upper part of the gradient where PREC increases and TEMP decreases, the number of rainy days and fog events is higher. Thus, bromeliad tanks in cloud forests may constantly hold water, prolonging anoxic conditions (Martinson et al. 2010; Goffredi et al. 2011; Lehours et al. 2016) and decreasing the rate of mass loss (Reddy and Patrick Jr 1975; Neckles and Neill 1994).

\section{Conclusions}

Our study showed that microsite (forest floor, branch surface and within tank bromeliads) interacts with climate (TEMP and PREC), which modifies the overall decomposition patterns in the canopy. Thus, it is premature to generalize that leaf litter decay is slower in the canopy than on the forest floor, especially in wet forest where precipitation and fog are common (e.g. cloud forest) and litter trapping plants are abundant and can increase litter decomposition. These findings are important for our understanding of the general carbon dynamics in the canopy, particularly in Neotropical forests. In such forests, arboreal soil can comprise half or more of the canopy's total organic matter (Nadkarni 1984; Nadkarni et al. 2004; Díaz et al. 2010; Gómez-González et al. 2017), bromeliads are by far the most important epiphytes in terms of biomass and abundance (Benzing 2000; Zotz 2016), and litter decomposition in these plants has been linked to methane emissions to the atmosphere, which Martinson et al. (2010) estimate to be $1.2 \mathrm{Tg} \mathrm{CH}_{4}$ year for all Neotropical forest. However, our study only focuses on the initial phase of litter decomposition in the forest canopy. Long-term decomposition experiments comparing both tea bags and local litter are needed to understand the later stages of litter decay, the formation of 
arboreal soil and to corroborate the patterns found in this study.

Acknowledgements The authors acknowledge Karina Osorio Salomón (INECOL), Susanne Töller (University Oldenburg), and José Emilio Aguilar Galván for their help during the fieldwork. We are also grateful for Ika Djukic (Environment Agency Austria), Carolina Ruiz Fernández (UNAM), and Hugo López Rosas (INECOL) for generating and providing decomposition data for Mexican mangroves, and for Allison Marie Jermain for reviewing the English style. The Functional Ecology department (INECOL) provided laboratory space and equipment to carry out this research. Y. Aguilar-Cruz was funded by the Consejo Nacional de Ciencia y Tecnología (CONACyT 408928) the Deutscher Akademischer Austauschdienst (DAAD 91569882) and the Heinz Neumüller Stiftung.

Open Access This article is licensed under a Creative Commons Attribution 4.0 International License, which permits use, sharing, adaptation, distribution and reproduction in any medium or format, as long as you give appropriate credit to the original author(s) and the source, provide a link to the Creative Commons licence, and indicate if changes were made. The images or other third party material in this article are included in the article's Creative Commons licence, unless indicated otherwise in a credit line to the material. If material is not included in the article's Creative Commons licence and your intended use is not permitted by statutory regulation or exceeds the permitted use, you will need to obtain permission directly from the copyright holder. To view a copy of this licence, visit http://creativecommons.org/licenses/by/4.0/.

Funding Open Access funding enabled and organized by Projekt DEAL.

\section{References}

Aerts R (1997) Leaf litter chemistry and leaf litter decomposition in terrestrial ecosystems: a triangular relationship. Oikos 79:439-449

Álvarez-Sánchez J, Guevara S (1999) Litter interception on Astrocaryum mexicanum Liebm. (Palmae) in a tropical rain forest. Biotropica 31:89-92

Anderson JT, Smith LM (2002) The effect of flooding regimes on decomposition of Polygonum pensylvanicum in playa wetlands (Southern Great Plains, USA). Aquat Bot 74:97-108. https://doi.org/10.1016/S03043770(02)00049-9

Ashcroft MB, Gollan JR (2013) Moisture, thermal inertia, and the spatial distributions of near-surface soil and air temperatures: understanding factors that promote microrefugia. Agric For Meteorol 176:77-89. https://doi.org/10. 1016/j.agrformet.2013.03.008

Austin AT, Vivanco L (2006) Plant litter decomposition in a semi-arid ecosystem controlled by photodegradation. Nature 442:555-558. https://doi.org/10.1038/nature05038
Bärlocher F (1991) Fungal colonization of fresh and dried leaves in the River Teign (Devon, England). Nov Hedwigia 52:349-357

Benzing DH (1987) Vascular epiphytism: taxonomic participation and adaptive diversity. Ann Missouri Bot Gard 74:183-204

Benzing DH (2000) Bromeliaceae: profile of an adaptive radiation. Cambridge University Press, Cambridge

Berg B, McClaugherty C (2014) Plant litter decomposition, humus formation, carbon sequestration, 3rd edn. Springer, Berlin Heidelberg

Berg B, Berg MP, Bottner P et al (1993) Litter mass loss rates in pine forests of Europe and Eastern United States: some relationships with climate and litter quality. Biogeochemistry 20:127-159. https://doi.org/10.1007/BF00000785

Bermudes D, Benzing DH (1991) Nitrogen fixation in association with Ecuadorean bromeliads. J Trop Ecol 7:531-536

Bohlman SA, Matelson TJ, Nadkarni NM (1995) Moisture and temperature patterns of canopy humus and forest floor soil of a montane cloud forest, Costa Rica. Biotropica 27:13-19

Bradford MA, Tordoff GM, Eggers T et al (2002) Microbiota, fauna, and mesh size interactions in litter decomposition. Oikos 99:317-323. https://doi.org/10.1034/j.1600-0706. 2002.990212.x

Bradford MA, Berg B, Maynard DS et al (2016) Understanding the dominant controls on litter decomposition. J Ecol 104:229-238. https://doi.org/10.1111/1365-2745.12507

Bradford MA, Ciska GF, Bonis A et al (2017) A test of the hierarchical model of litter decomposition. Nat Ecol Evol 1:1836-1845. https://doi.org/10.1038/s41559-017-0367-4

Brooks ME, Kristensen K, van Benthem KJ et al (2017) glmmTMB balances speed and flexibility among packages for zero-inflated generalized linear mixed modeling. R J 9:378-400. https://doi.org/10.32614/rj-2017-066

Callaway RM, Reinhart KO, Moore GW et al (2002) Epiphyte host preferences and host traits: mechanisms for speciesspecific interactions. Oecologia 132:221-230. https://doi. org/10.1007/s00442-002-0943-3

Cardelús CL (2010) Litter decomposition within the canopy and forest floor of three tree species in a tropical lowland rain forest, Costa Rica. Biotropica 42:300-308

Cházaro-Basáñez MJ (1992) Exploraciones botánicas en Veracruz y estados circunvecinos I. Pisos altitudinales de vegetación en el centro de Veracruz y zonas limítrofes con Puebla. La Cienc y el Hombre 10:67-115

Clark KL, Nadkarni NM, Gholz HL (1998) Growth, net production, litter decomposition, and net nitrogen accumulation by epiphytic bryophytes in a tropical montane forest. Biotropica 30:12-23. https://doi.org/10.1111/j.1744-7429. 1998.tb00365.x

Clein JS, Schimel JP (1994) Reduction in microbial activity in Birch litter due to drying and rewetting event. Soil Biol Biochem 26:403-406. https://doi.org/10.1016/00380717(94)90290-9

CONABIO (2011) La biodiversidad en Veracruz: estudio de estado. Volumen I. Comisión Nacional para el Conocimiento y Uso de la Biodiversidad (CONABIO), Gobierno del Estado de Veracruz, Universidad Veracruzana, Instituto de Ecología, A. C., Mexico

CONABIO, INIFAP (1995) Edafología. Escala 1:1000000. México. https://www.conabio.gob.mx/informacion/ 
metadata/gis/eda251mgw.xml?_httpcache=yes\&_xsl=/db/ metadata/xsl/fgdc_html.xsl\&_indent=no. Accessed 1 July 2019

Cornwell WK, Cornelissen JHC, Amatangelo K et al (2008) Plant species traits are the predominant control on litter decomposition rates within biomes worldwide. Ecol Lett 11:1065-1071. https://doi.org/10.1111/j.1461-0248.2008. 01219.x

Coûteaux MM, Bottner P, Berg B (1995) Litter decomposition, climate and liter quality. Trends Ecol Evol 10:63-66. https://doi.org/10.1016/S0169-5347(00)88978-8

Davidson EA, Janssens IA, Marks D et al (2006) Temperature sensitivity of soil carbon decomposition and feedbacks to climate change. Nature 440:165-173. https://doi.org/10. 1038/nature04514

Dearden FM, Wardle DA (2008) The potential for forest canopy litterfall interception by a dense fern understorey, and the consequences for litter decomposition. Oikos 117:83-92. https://doi.org/10.1111/j.2007.0030-1299.16136.x

Delamare-Deboutteville C (1948) Étude quantitative du peuplement animal des suspendus et des Épiphytes en forét tropicale. Comptes Rendus L'Academie Des Sci Ser III Sci La Vie 226:1544-1546

Díaz IA, Sieving KE, Peña-Foxon ME et al (2010) Epiphyte diversity and biomass loads of canopy emergent trees in Chilean temperate rain forests: a neglected functional component. For Ecol Manag 259:1490-1501. https://doi. org/10.1016/j.foreco.2010.01.025

Dick TM, Osunkoya OO (2000) Influence of tidal restriction floodgates on decomposition of mangrove litter. Aquat Bot 68:273-280. https://doi.org/10.1016/S03043770(00)00119-4

Didion M, Repo A, Liski J et al (2016) Towards harmonizing leaf litter decomposition studies using standard tea bags-a field study and model application. Forests 7:1-12. https:// doi.org/10.3390/f7080167

Djukic I, Kepfer-Rojas S, Schmidt IK et al (2018) Early stage litter decomposition across biomes. Sci Total Environ 628-629:1369-1394. https://doi.org/10.1016/j.scitotenv. 2018.01.012

Douma JC, Weedon JT (2019) Analysing continuous proportions in ecology and evolution: a practical introduction to beta and Dirichlet regression. Methods Ecol Evol 10:1412-1430. https://doi.org/10.1111/2041-210X.13234

Einzmann HJR, Beyschlag J, Hofhansl F et al (2015) Host tree phenology affects vascular epiphytes at the physiological, demographic and community level. AoB Plants. https:// doi.org/10.1093/aobpla/plu073

Enloe HA, Graham RC, Sillett SC (2006) Arboreal histosols in old-growth redwood forest canopies, Northern California. Soil Sci Soc Am J 70:408-418. https://doi.org/10.2136/ sssaj2004.0229

Enríquez S, Duarte C, Sand-Jensen K (1993) Patterns in decomposition rates among photosynthetic organisms: the importance of detritus C: N: P content. Oecologia 94:457-471. https://doi.org/10.1007/BF00566960

Fick SE, Hijmans RJ (2017) WorldClim 2: new 1-km spatial resolution climate surfaces for global land areas. Int $\mathbf{J}$ Climatol 37:4302-4315. https://doi.org/10.1002/joc.5086
Fonte SJ, Schowalter TD (2004) Decomposition in forest canopies. In: Lowman MD, Rinker HB (eds) Forest canopies, 2nd edn. Elsevier, Burlington, pp 413-422

Fragoso C, Rojas-Fernández P (1996) Earthworms inhabiting bromeliads in Mexican tropical rainforests: ecological and historical determinants. J Trop Ecol 12:729-734. https:// doi.org/10.1017/S0266467400009925

Gessner MO (1991) Differences in processing dynamics of fresh and dried leaf litter in a stream ecosystem. Freshw Biol 26:387-398. https://doi.org/10.1111/j.1365-2427.1991. tb01406.x

Goffredi SK, Kantor AH, Woodside WT (2011) Aquatic microbial habitats within a neotropical rainforest: bromeliads and $\mathrm{pH}$-associated trends in bacterial diversity and composition. Microb Ecol 61:529-542. https://doi.org/ 10.1007/s00248-010-9781-8

Gómez-González D, Rodríguez-Quiel C, Zotz G, Bader M (2017) Species richness and biomass of epiphytic vegetation in a tropical montane forest, western Panama. Trop Conserv Sci 10:1-17. https://doi.org/10.1177/ 1940082917698468

Gora EM, Lucas JM (2019) Dispersal and nutrient limitations of decomposition above the forest floor: evidence from experimental manipulations of epiphytes and macronutrients. Funct Ecol 33:2417-2429. https://doi.org/10.1111/ 1365-2435.13440

Hofstede RGM, Dickinson KJM, Mark AF (2001) Distribution, abundance and biomass of epiphyte-lianoid communities in a New Zealand lowland Nothofagus-podocarp temperate rain forest: Tropical comparisons. J Biogeogr 28:1033-1049. https://doi.org/10.1046/j.1365-2699.2001. 00613.x

Ibrahima A, Joffre R, Gillon D (1995) Changes in litter during the initial leaching phase: an experiment on the leaf litter of Mediterranean species. Soil Biol Biochem 27:931-939. https://doi.org/10.1016/0038-0717(95)00006-Z

Inselsbacher E, Cambui CA, Richter A et al (2007) Microbial activities and foliar uptake of nitrogen in the epiphytic bromeliad Vriesea gigantea. New Phytol 175:311-320. https://doi.org/10.1111/j.1469-8137.2007.02098.x

Keuskamp JA, Dingemans BJJ, Lehtinen T et al (2013) Tea Bag Index: a novel approach to collect uniform decomposition data across ecosystems. Methods Ecol Evol 4:1070-1075. https://doi.org/10.1111/2041-210X.12097

LeCraw RM, Romero GQ, Srivastava DS (2017) Geographic shifts in the effects of habitat size on trophic structure and decomposition. Ecography (Cop) 40:1445-1454. https:// doi.org/10.1111/ecog.02796

Lee H, Fitzgerald J, Hewins DB et al (2014) Soil moisture and soil-litter mixing effects on surface litter decomposition: a controlled environment assessment. Soil Biol Biochem 72:123-132. https://doi.org/10.1016/j.soilbio.2014.01.027

Lehours AC, Le Jeune AH, Aguer JP et al (2016) Unexpectedly high bacteriochlorophyll a concentrations in neotropical tank bromeliads. Environ Microbiol Rep 8:689-698. https://doi.org/10.1111/1758-2229.12426

Lenth RV (2016) Least-squares means: the R package lsmeans. J Stat Softw. https://doi.org/10.18637/jss.v069.i01

Li S, Liu WY, Li DW et al (2014) Slower rates of litter decomposition of dominant epiphytes in the canopy than on the forest floor in a subtropical montane forest, 
southwest China. Soil Biol Biochem 70:211-220. https:// doi.org/10.1016/j.soilbio.2013.12.031

Lindo Z, Winchester NN (2006) A comparison of microarthropod assemblages with emphasis on oribatid mites in canopy suspended soils and forest floors associated with ancient western redcedar trees. Pedobiologia 50:31-41. https://doi.org/10.1016/j.pedobi.2005.09.002

Lindo Z, Winchester NN (2007) Oribatid mite communities and foliar litter decomposition in canopy suspended soils and forest floor habitats of western redcedar forests, Vancouver Island, Canada. Soil Biol Biochem 39:2957-2966. https:// doi.org/10.1016/j.soilbio.2007.06.009

Liu G, Cornwell WK, Pan X et al (2015) Decomposition of 51 semidesert species from wide-ranging phylogeny is faster in standing and sand-buried than in surface leaf litters: implications for carbon and nutrient dynamics. Plant Soil 396:175-187. https://doi.org/10.1007/s11104-015-2595-1

Loescher H, Ayres E, Duffy P et al (2014) Spatial variation in soil properties among North American ecosystems and guidelines for sampling designs. PLoS ONE. https://doi. org/10.1371/journal.pone.0083216

López-Portillo J, Ezcurra E (2002) Los manglares de México: una revisión. Madera y Bosques 8:27-51

Lüdecke D, Waggoner P, Makowski D (2019) insight: a unified interface to access information from model objects in R. J Open Source Softw 4:1412. https://doi.org/10.21105/joss. 01412

Manzoni S, Schimel JP, Porporato A (2012) Responses of soil microbial communities to water stress: results from a metaanalysis. Ecology 93:930-938. https://doi.org/10.1890/110026.1

Martinson GO, Werner FA, Scherber C et al (2010) Methane emissions from tank bromeliads in neotropical forests. Nat Geosci 3:766-769. https://doi.org/10.1038/ngeo980

Nadkarni NM (1984) Epiphyte biomass and nutrient capital of a neotropical elfin forest. Biotropica 16:249-256

Nadkarni NM (1994) Diversity of species and interactions in the upper tree canopy of forest ecosystems. Am Zool 34:70-78

Nadkarni NM, Longino JT (1990) Invertebrates in canopy and ground organic matter in a Neotropical montane forest, Costa Rica. Biotropica 22:286-289

Nadkarni NM, Matelson TJ (1991) Fine litter dynamics within the tree canopy of a tropical cloud forest. Ecology 72:2071-2082

Nadkarni NM, Schaefer D, Matelson TJ, Solano R (2002) Comparison of arboreal and terrestrial soil characteristics in a lower montane forest, Monteverde, Costa Rica. Pedobiologia (Jena) 46:24-33

Nadkarni NM, Schaefer D, Matelson TJ, Solano R (2004) Biomass and nutrient pools of canopy and terrestrial components in a primary and a secondary montane cloud forest, Costa Rica. For Ecol Manag 198:223-236. https:// doi.org/10.1016/j.foreco.2004.04.011

Nakagawa S, Schielzeth H (2013) A general and simple method for obtaining R2 from generalized linear mixed-effects models. Methods Ecol Evol 4:133-142. https://doi.org/10. 1111/j.2041-210x.2012.00261.x

Neckles HA, Neill C (1994) Hydrologic control of litter decomposition in seasonally flooded prairie marshes. Hydrobiologia 286:155-165. https://doi.org/10.1007/ BF00006247
Nykvist N (1963) Leaching and decomposition of water-soluble organic substances from different types of leaf and needle litter. Stud For Suec 3:1-31

Ortega-Solís G, Díaz I, Mellado-Mansilla D et al (2017) Ecosystem engineering by Fascicularia bicolor in the canopy of the South-American temperate rainforest. For Ecol Manag 400:417-428. https://doi.org/10.1016/j. foreco.2017.06.020

Paoletti MG, Taylor RAJ, Stinner BR et al (1991) Diversity of soil fauna in the canopy and forest floor of a Venezuelan cloud forest. J Trop Ecol 7:373-383. https://doi.org/10. 1017/S0266467400005654

Parton WJ, Logan JA (1981) A model for diurnal variation in soil and air temperature. Agric Meteorol 23:205-216. https://doi.org/10.1016/0002-1571(81)90105-9

Petraglia A, Cacciatori C, Chelli S et al (2019) Litter decomposition: effects of temperature driven by soil moisture and vegetation type. Plant Soil 435:187-200. https://doi.org/ 10.1007/s11104-018-3889-x

Pittl E, Innerebner G, Wanek W, Insam H (2010) Microbial communities of arboreal and ground soils in the Esquinas rainforest, Costa Rica. Plant Soil 329:65-74. https://doi. org/10.1007/s11104-009-0134-7

Prescott CE (2010) Litter decomposition: what controls it and how can we alter it to sequester more carbon in forest soils? Biogeochemistry 101:133-149. https://doi.org/10.1007/ s10533-010-9439-0

R Core Team (2020) R: a language and environment for statistical computing. R Foundation for Statistical Computing, Vienna, Austria

Reddy K, Patrick W Jr (1975) Effect of alternate aerobic and anaerobic conditions on redox potential, organic and nitrogen in a flooded soil. Soil Biol Biochem 7:87-94. https://doi.org/10.1046/j.1471-8278.2001.00047.x

Santos PF, Elkins NZ, Steinberger Y, Whitford WG (1984) A comparison of surface and buried Larrea tridentata leaf litter decomposition in North American hot deserts. Ecol Soc Am 65:278-284

Scheffers BR, Phillips BL, Shoo LP (2014) Asplenium bird's nest ferns in rainforest canopies are climate-contingent refuges for frogs. Glob Ecol Conserv 2:37-46. https://doi. org/10.1016/j.gecco.2014.06.004

Seastedt TR (1984) The role of microarthropods in decomposition and mineralization processes. Annu Rev Entomol 29:25-46

Šnajdr J, Cajthaml T, Valášková V et al (2011) Transformation of Quercus petraea litter: successive changes in litter chemistry are reflected in differential enzyme activity and changes in the microbial community composition. FEMS Microbiol Ecol 75:291-303. https://doi.org/10.1111/j. 1574-6941.2010.00999.x

Steinke TD, Holland AJ, Singh Y (1993) Leaching losses during decomposition of mangrove leaf litter. S Afr J Bot 59:21-25. https://doi.org/10.1016/s0254-6299(16)30770-0

Stuntz S, Simon U, Zotz G (2002) Rainforest air-conditioning: the moderating influence of epiphytes on the microclimate in tropical tree crowns. Int J Biometeorol 46:53-59. https:// doi.org/10.1007/s00484-001-0117-8

Sugden AM, Robins RJ (1979) Aspects of the ecology of vascular epiphytes in colombian cloud forests, I. The distribution of the epiphytic flora. Biotropica 11:173-188 
Swift MJ, Healey IN, Hibberd JK et al (1976) The decomposition of branch-wood in the canopy and floor of a mixed deciduous woodland. Oecologia 26:139-149

Vance ED, Nadkarni NM (1990) Microbial biomass and activity in canopy organic matter and the forest floor of a tropical cloud forest. Soil Biol Biochem 22:677-684. https://doi. org/10.1016/0038-0717(90)90015-R

Verhoef HA, Brussaard L (1990) Decomposition and nitrogen mineralization in natural and agro- ecosystems: the contribution of soil animals. Biogeochemistry 11:175-211. https://doi.org/10.1007/Bf00004496

Voříšková J, Baldrian P (2013) Fungal community on decomposing leaf litter undergoes rapid successional changes. ISME J 7:477-486. https://doi.org/10.1038/ismej.2012. 116

Wall DH, Bradford MA, St. John MG et al (2008) Global decomposition experiment shows soil animal impacts on decomposition are climate-dependent. Glob Chang Biol 14:2661-2677. https://doi.org/10.1111/j.1365-2486.2008. 01672.x

Wang Y, Hao Y, Cui XY et al (2014) Responses of soil respiration and its components to drought stress. J Soils Sediments 14:99-109. https://doi.org/10.1007/s11368-0130799-7

Yahdjian L, Sala OE, Austin AT (2006) Differential controls of water input on litter decomposition and nitrogen dynamics in the patagonian steppe. Ecosystems 9:128-141. https:// doi.org/10.1007/s10021-004-0118-7

Zhang DQ, Hui DF, Luo YQ, Zhou GY (2008) Rates of litter decomposition in terrestrial ecosystems: global patterns and controlling factors. J Plant Ecol 1:85-93. https://doi. org/10.1093/Jpe/Rtn002

Zona S, Christenhusz MJM (2015) Litter-trapping plants: filterfeeders of the plant kingdom. Bot J Linn Soc 179:554-586. https://doi.org/10.1111/boj.12346

Zotz G (2016) Plants on plants - The biology of vascular epiphytes. Springer, Switzerland

Zotz G, Thomas V (1999) How much water is in the tank? Model calculations for two epiphytic bromeliads. Ann Bot 83:183-192. https://doi.org/10.1006/anbo.1998.0809

Zotz G, Hietz P (2001) The physiological ecology of vascular epiphytes: current knowledge, open questions. J Exp Bot 52:2067-2078. https://doi.org/10.1093/jexbot/52.364. 2067

Zotz G, Leja M, Aguilar-Cruz Y, Einzmann HJR (2020) How much water is in the tank? An allometric analysis with 205 bromeliad species. Flora 264:151557. https://doi.org/10. 1016/j.flora.2020.151557

Publisher's Note Springer Nature remains neutral with regard to jurisdictional claims in published maps and institutional affiliations. 